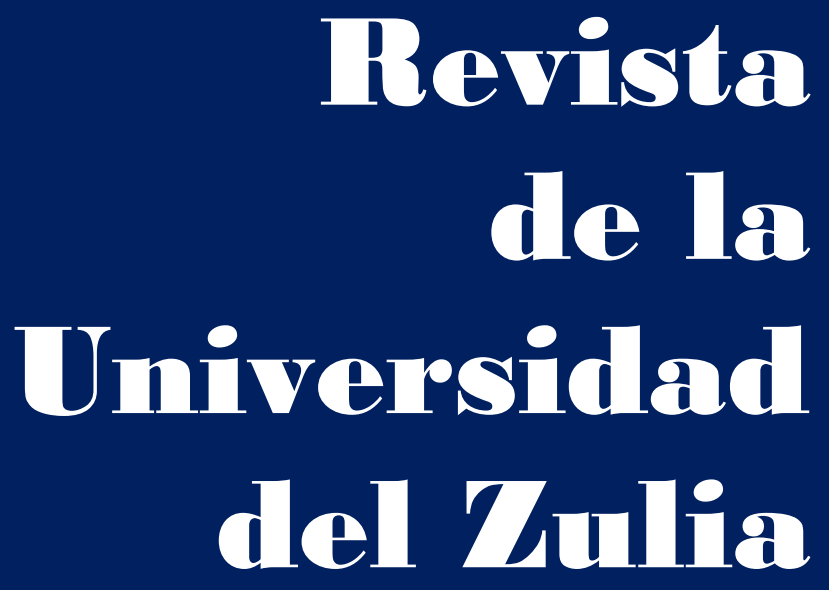

Fundada en 1947

por el Dr. Jesús Enrique Lossada

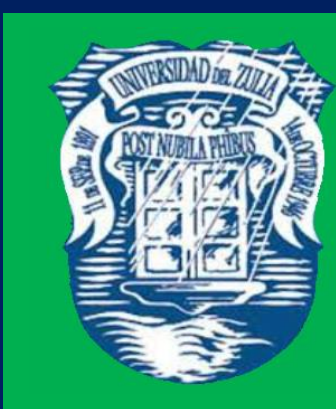

Ciencias del

Agred

Ingemieria

y Teenología
Añต 12 No 32

Enero - Abril 2021

Tercera Época

Maracailbo-Venezuela 
REVISTA DE LA UNIVERSIDAD DEL ZULIA. $3^{2}$ época. Año $12 \mathrm{~N}^{\circ}$ 32, 2021

\title{
Legal technologies as instruments of civil aviation safety improvement in conditions of the fight against COVID-2019
}

\author{
Oksana Myronets * \\ Viktor Olefir ** \\ Ivan Golosnichenko *** \\ Yuriy Pyvovar ****
}

\begin{abstract}
Purpose of the paper is to determine current issues and prospective directions of the legal technologies' use for civil aviation safety improvement and future development under modern COVID-2019, post-pandemic challenges and conditions of the new world's order. By using the dialectical method, the current conceptual framework and issues of the legal technologies as instruments of civil aviation safety improvement have been formulated. The formal-dogmatic method contributed to the development of the authors' explanation of the current state, issues, challenges, and practical role of the legal technologies for the further improvement of civil aviation safety under the fight against COVID-2019. In the paper modern challenges to the legal technologies' use for civil aviation safety improvement in pandemic and post-pandemic conditions have been analyzed. Prospects of the legal technologies' effective implementation for the future civil aviation safety improvement in conditions of pandemic, post-pandemic and new world's order have been suggested.
\end{abstract}

KEYWORDS: civil aviation; safety; pandemics; legislation; technological change.

*Ph.D. in Law, Associate Professor of Constitutional and Administrative Law Department, Law Faculty, National Aviation University, 1 Liubomyr Huzar Avenue, Kyiv, 03058, Ukraine, ORCID ID: https://orcid.org/0000-0002-5035-2384. E-mail: myronetsoxi@i.ua

**D.Sc. in Law, Professor, National Academy of Law of Ukraine, 70 Pushkinskaya Street, 61024, Kharkiv, Ukraine. ORCID ID: https:/orcid.org/0000-0002-64-32-8537. E-mail: viktorolefir@i.ua

***D.Sc. in Law, Professor, Kyiv Institute of Intellectual property and right, National University "Odesa Law Academy", Kyiv, Ukraine. ORCID ID: https://orcid.org/0000-0003-2069-4372. E-mail: golosnichenkopantelei@i.ua

****Professor, Ph.D. in Law, Head of Constitutional and Administrative Law Department, Law Faculty, National Aviation University, 1 Liubomyr Huzar Avenue, Kyiv, 03058, Ukraine. ORCID ID: https:/orcid.org/0000-0001-8258-7930 Scopus ID: 57203992023; Web of Science ID: O-4973-2016 *Corresponding author: E-mail: pyvovaryi@gmail.com

Recibido: 13/10/2020

Aceptado: 07/12/2020 


\section{Tecnologías legales como instrumentos para la mejora de la seguridad de la aviación civil en las condiciones de la lucha contra COVID-2019}

RESUMEN

El propósito del artículo es determinar los problemas actuales y las direcciones prospectivas del uso de las tecnologías legales para la mejora de la seguridad en la aviación civil, el desarrollo futuro bajo el COVID -2019, los desafíos posteriores a la pandemia y las condiciones del nuevo orden mundial. Utilizando el método dialéctico, se han formulado el marco conceptual actual y las cuestiones de las tecnologías legales como instrumentos de mejora de la seguridad operacional de la aviación civil. El método formal-dogmático contribuyó al desarrollo de la explicación de los autores sobre el estado actual, los problemas, los desafíos y el papel práctico de las tecnologías legales para la mejora adicional en la seguridad de la aviación civil en la lucha contra el COVID-2019. En el artículo se analizan los desafíos modernos al uso de tecnologías legales para mejorar la seguridad de la aviación civil en condiciones pandémicas y pospandémicas. Se han sugerido perspectivas de implementación efectiva de las tecnologías legales para la futura mejora de la seguridad de la aviación civil en condiciones de pandemia, pospandemia y el nuevo orden mundial.

PALABRAS CLAVE: aviación civil; la seguridad; pandemias; legislación; cambio tecnológico.

Introduction

Safety is an ordinary requirement for every type of social activity, including commercial in different spheres of economy. Without any doubts, the civil aviation industry is one the most developed and fast field where the issue of safe existence and functioning is not just a theoretical category for the scientific investigations, but a practical need that is discussed and supported by all aviation countries of the world under the attentive participation and even supervision of international organizations. Due to this fact, the progressive development of aviation in this or that territorially separated state is always made just in accordance with direct and strong world aviation policy that has the prevailing position in relation to the national aviation policy of such a country. The key moment in this belong and will be always connected with the urgent and constant need of the whole aviation community in safe air transportations because consequences in case of airplanes crash can 
REVISTA DE LA UNIVERSIDAD DEL ZULIA. $3^{2}$ época. Año 12 N$^{\circ}$ 32, 2021

never be limited by official decisions of national public officers if they have their dangerous and destructive influence on the territory of several states.

In the civil aviation industry safety is considered as non-negotiable assets that need to be put on top of the list (Hasmin et al., 2017). Safety in civil aviation is an intransitive issue for every aviation state and aviation community as a whole to satisfy the needs of its commercial use, protect its participants and so-called third people from any related danger. The status of being intransitive for the category "aviation safety" is based on internationally accepted attitude to the requirement of as more as practically possible rapid aviation adaptation to hazards of any nature.

Globally, civil aviation has been marked by two general trends: increasing traffic volume and an improving safety record (Pramono et al., 2020).

Nowadays, we may notice a bright example of such a complicated challenge for the whole aviation industry that is represented by pandemic conditions and negative consequences connected with them.

This is a challenge as while commercial air transport operations lend themselves well to high levels of regulation, they cannot be translated literally to healthcare, with its associated unknowns and variables (Hardie \& Brennan, 2020). The world's community suggested different measures to stabilize the situation and ensure the possibility for its further differently directed development. The nature of the mentioned proposals is characterized by the variety of their content and essence. In general, all of them being technically, legally, economically and so on oriented may be determined as specific technologies that are used strategically for the future of the world's civil aviation in pandemic and even post pandemic conditions of its development.

Among them, it is relevant to distinguish legal means as technologies of national and international levels that are to provide civil aviation safety under the official control of national governments and international organizations in the field of aviation transport.

The COVID-19 threat provides critical legal scholarship with a unique opportunity, despite all of the current and future uncertainties and speculations, to move far beyond the mainstream understanding of the economic constitution and private law (Micklitz, 2020).

Thus, the purpose of the article is to determine current issues and prospective of the legal technologies use to improve civil aviation safety under the fight against COVID-2019 
REVISTA DE LA UNIVERSIDAD DEL ZULIA. $3^{2}$ época. Año $12 \mathrm{~N}^{\circ}$ 32, 2021

and in post pandemic conditions. To achieve this aim it is needed to perform the following tasks: 1) to consider theoretical-legal fundamentals of the legal technologies and their practical role in civil aviation safety improvement; 2) to analyze the current state, issues and challenges to the legal technologies for the civil aviation safety in pandemic conditions; 3) to investigate particularities and suggest prospects of the legal technologies use in the civil aviation safety further improvement and development in post pandemic reality.

The mentioned tasks are to investigate a subject of the article that is legal technologies as instruments of civil aviation safety improvement in modern conditions of the fights against COVID-2019 taking into account the legally regulated relations in the sphere of civil aviation safety implementation that is an object of the paper.

\section{Methods}

To achieve the aim of the article, general-scientific and special-legal methods of cognition have been applied.

By using the dialectical method, the current conceptual framework and issues of the legal technologies as instruments of civil aviation safety improvement have been formulated.

The formal-dogmatic method contributed to the development of the authors' explanation of the current state, issues, challenges, and practical role of the legal technologies for the further development and improvement of civil aviation safety under the fight against COVID-2019.

The formal-legal method gave the opportunity to suggest the directions and kinds of legal technologies use as the prospects for the improvement of civil aviation safety in modern pandemic and post pandemic conditions.

\section{Results}

Investigating a concept of legal technologies, we have to result that in conditions of pandemic and post pandemic reality they may be effectively used by national governments and involved international organizations as practically constructive instruments of the development and improvement of civil aviation safety that describes their essential role in current and future aviation policy for the whole aviation community's existence and functioning. 
REVISTA DE LA UNIVERSIDAD DEL ZULIA. $3^{2}$ época. Año $12 \mathrm{~N}^{\circ}$ 32, 2021

Among currents challenges to legal technologies effective use to ensure the improvement of civil aviation safety in pandemic conditions we have to mention not just outside negative COVID-2019 influence, but also inside technical non-readiness, political non-coordination, economic non-willingness of civil aviation system administration by use of appropriate legal technologies as the platform for peoples' protection in conditions of the commercial income decrease as an objective and logically acceptable need.

Thus, we suggested to understand and use the legal technologies as the regulatoryprotective basis for the modern aviation safety policy formation that has to be represented by the safety improvement in relation to 1) airports and their personnel activity; 2) aircraft functioning and their personnel activity; 3) transportation of passengers, their luggage with the taking of special attention to animals, and cargo by air. The measures that are suggested by the modern legal technologies may be divided into social-self-preventive, ideologicaleducative and technical ones.

The whole civil aviation community's adequate reaction on and appropriate acceptance of the suggested directions for the aviation industry safety improvement creates a required fundament for its future existence and effective functioning in modern post pandemic reality under the rapid cyber technologies development involving cyber humans further participation as a part of aviation personnel and consumers of aviation services under the new world's order.

\section{Discussion}

3.1. Fundamentals of legal technologies and their practical influence on civil aviation safety improvement in the COVID-2019 conditions

Among the composite parts of civil aviation safety legal component takes a specific place due to its generally significant role for the whole system of safety in the sphere of commercial air transport.

At the same time, the contents and essence of the mentioned legally oriented part as a legal technology to be used for the improvement of current state and response to present challenges for the world's aviation in pandemic times is not investigated fully. Thus, this gape requires its filling to resolve a significant scientific task of today's reality that is stabilization and improvement of civil aviation safety by any possible means, including legal, for the 
further effective functioning and development of civil aviation under the fight against COVID-2019 and in post pandemic conditions.

To our point of view, the practically useful influence of legal technologies in general and on the state of civil aviation safety, in particular, is directly connected with the deep theoretical understanding of their nature. Under the urgent need to ensure the stabilization of the currents situation in the field of safe transportations by air under the world's pandemic, science has to pay its attention to the phenomena of the mentioned technologies to find the directions of their most productive and useful implementation in modern conditions of the whole mankind response on global socially transformed challenges.

3.1.1. Conceptual understanding of legal technologies in legal regulation and protection of social relations to ensure civil aviation safety

Regulation and protection of social relations by the means of legal nature is made by a system of special generally accepted regulators of such relations acceptable for this or that country according to their differently oriented development.

States' evolution is a complicated phenomenon that is based on political-economic, historical, social-cultures and within the last component traditional-religious conditions and peculiarities of their origin. In most secular countries officially adopted rules by state bodies with legislative plenary power are the socially accepted regulators of differently natured legal relations and further development of such states. Thus, the mentioned norms are understood as specific and appropriate instruments for a certain state on a definite stage of its existence according to the outside and inside conditions of its own development. The prevailing role in such a process is plaid by the state's rules that provide regulative and protective policy in different branches of the state's and its people's activity. In our point of view, the value of these norms in their practical ability to be specific technologies of legal nature that are effectively used by modern state power in the providing of modern public administration for the improvement and stable development of their countries.

Being juridically acceptable, the concept of legal technologies is still new for legal science. On the one hand, norms of law as regulators of social relations are known for this part of scientific cognition. On the other hand, we insist that in conditions of modern global reality under social transformations and the world's fight against COVID-2019 directly the term "legal technologies" describes the essence of such regulators of modern nature under 
REVISTA DE LA UNIVERSIDAD DEL ZULIA. $3^{2}$ época. Año $12 \mathrm{~N}^{\circ}$ 32, 2021

recent complicated conditions and expresses the contemporary significance of their constructive influence on modern societies.

Thus, to according to our position, a concept of legal technologies in pandemic and post pandemic times may be understood as regulatory-protective instruments that are used by national governments and involved international organizations for the development and improvement of civil aviation safety and providing the appropriate aviation policy under the requirements and needs of reality.

3.1.2. Role and significance of legal technologies in the system of civil aviation safety ensuring

Identification of any phenomenon role may be understood just by its comparing with similar phenomena and according to an approach of their interconnection and vision them as existing in a common system. Thus, it is needed to analyze a system of civil aviation safety to estimate the role of legal technologies for such a system and its efficient functioning especially in non-ordinary pandemic and post pandemic reality.

For instance, according to the item 20 of the part 1 of the article lof the Air Code of Ukraine, aviation safety is the state of the civil aviation industry, where the risk of causing damage to people or property is reduced to an acceptable level as a result of a continuous process of determining and controlling the level of danger and maintained at that level, or decreases further, in the areas of flight safety, aviation security, environmental safety, economic security and informational safety (2011). Taking into account the mentioned above, the direct structure of aviation safety is represented in the part 1 of the article 10 of the Air Code of Ukraine by the formulation that it consists of flight safety, aviation security, environmental safety, economic safety and informational safety (2011).

Thus, legal technologies are not determined directly as an integral part of safety in the sphere of civil aviation. At the same time, under strict analysis it is possible to make a conclusion that the mentioned technologies are not just indissolubly part of civil aviation safety, but they determine the level of safety in all integral components of its whole structure. More else, legal technologies play such a significant role on the level of a separate country and on the level of the whole aviation world.

We mean that effective and appropriate regulative-protective measures provided by aviation states and organizations in the sphere of civil aviation such as, for example, 
REVISTA DE LA UNIVERSIDAD DEL ZULIA. $3^{2}$ época. Año $12 \mathrm{~N}^{\circ}$ 32, 2021

International Civil Aviation Organization, in conditions of the fight against COVID-2019 and for the further post pandemic reality determine the appropriate and practically needed directions to improve flight safety, aviation security, environmental safety, economic safety, informational safety separately, and, thus, aviation safety in general. Nowadays, national and international legal technologies are the local and world's instruments for the gradually accepted but systematic influence and control for the civil aviation safety improvement in pandemic and post pandemic conditions.

The idealistic aspiration of zero accidents, albeit statistically unachievable, keeps everyone in the aviation profession focused on building an increasingly safe aviation system (Balcerzak, 2017). We think that only legal technologies under the pandemic as the challenge for the aviation industry proper functioning may be not just a valuable, but the developmentoriented instrument.

More else, even safeguarding civil aviation against acts of unlawful interference may be taken by applying legal solutions as well as preventive actions. The latter solutions, aimed at ensuring security, and thus securing civil aviation against acts of unlawful interference, can be used and implemented at airports, on board aircraft, and through the use of operational solutions (Sliwinska, 2019).

Improving the organization of air transport security system, including the increase of efficiency of aviation counter-terrorism, will require changes in methods and ways of using forces and measures, modification of operating procedures, as well as changes in legislation (Radomyskia \& Bernat, 2018).

The mentioned above fully describes their significant role in civil aviation safety improvement policy and opens its readiness to new expected and unexpected challenges in a rapidly developed informational world.

3.2. Currents issues and prospects of the legal technologies use for the further civil aviation safety development in pandemic and post pandemic conditions

Taking into account commercial profit loss as the biggest challenge for the aviation industry under the pandemic, it is needed to be careful to suggest directions and measures for further civil aviation safety improvement because they are connected with the involvement of monetary resources too. 
REVISTA DE LA UNIVERSIDAD DEL ZULIA. $3^{2}$ época. Año $12 \mathrm{~N}^{\circ}$ 32, 2021 Oksana Myronets et al. // Legal technologies as instruments of civil aviation safety... 444-459 DOI: http://dx.doi.org/10.46925//rdluz.32.26

This has clear implications for the aviation industry as well as indirect consequences to several sectors (e.g.tourism) and the economy at large as well as the society (Iacus, et. al., 2020). At the same time, COVID-2019 created a dilemma of choosing between the high possibility of human health and life loss for the sake of commercial gains in the aviation industry and the loss of commercial profits in the mentioned field for the sake of human health and life-saving. New health screening controls would be imposed at airports, translating in higher costs for airports and passengers (Suau-Sanchez, Voltes-Dorta \& Cuguero-Escofet, 2020).

Logically the first of more profitable but limited by the quantity of civil aviation users in a separate country and in the whole world. More else, this way is destructive from the beginning because under the total absence of passengers for their transportation by air, civil aviation's role may be significantly low even taking into account the world's needs in cargo transportations by air.

Thus, even under the acceptable commercial loss civil aviation is under the necessity to make appropriate rules for the increase of its safety in pandemic and post pandemic conditions. The complex of such rules, to our mind, has to be represented by an efficient and modern system of legal technologies for the stable functioning of the aviation industry under safe transportations by air.

More else, COVID-19 has demonstrated that, rather than having airports and airlines change their practices alone, it is necessary that States change their practices along with them in a uniform and widespread manner. Considering that COVID-19 affected various sectors in various locations, change should be spurred not only on a micro-scale, that is, by the various stakeholders of the various industries so affected, but also on a macro-scale, that is, by the different governments of the world. Change, therefore, can only be achieved by all acting as one (Cassar, 2020).

3.2.1. Current challenges for the legal technologies implementation for the civil aviation safety improvement under the fight against COVID-2019

The challenges for the use of legal technologies with the aim to improve the state of safety in the field of modern civil aviation may be represented by their dividing on external and internal. 
Among the first, we have to stress on pandemic existence with its negative consequences on both sides of aviation relations. On the one hand, airports and airplane personnel as providers of aviation service need the increase of safety under the fight against COVID-2019. On the other hand, for example, passengers as consumers of aviation service require their safe transportations that have to be done under the change of ordinary conditions and the transformation of protective measures for movement by air. One more element in this process belongs to a so-called psychological component due to the increase of stressful levels for the human psyche for being transported by air in conditions of adaptive quarantine as a reaction to pandemic existence.

The second group of challenges originates from the internal disagreements in the civil aviation component support and functioning. The first of them is represented by the technical non-readiness of this industry to own automatic evolution due to the pandemic conditions. We mean that even being rather developed technically, the aviation sphere was not prepared and, thus, did not have its predictive technical reaction on the total change of ordinary requirements for cargo, passengers, and their luggage transportation in extreme conditions.

More else, in civil protection airport systems, it is essential to consider, for example, potential risks to the airport, the vast terrain to be guarded by Aviation Security Service and other services, a specific airport infrastructure, passenger and freight traffic (Nowak, Ogonowski \& Kustra, 2019).

Also, there is a second integral element that may be determined as the political noncoordination between national governments in providing aviation policy under the fight against COVID-2019 but within the international civil aviation functioning requirements. Thus, the last regulation also had to be rapidly adapted in differently-oriented directions to stabilize the current state of civil aviation safety and suggest its improvement.

The third component is represented by the economic non-willingness of the civil aviation system administration to commercial loss due to the decrease of aviation transportation quantity in the pandemic, and to the additional spending for the airports and airplanes safety improvement as well as the aviation personnel protection in non-ordinary conditions under the requirements of modern legal technologies. 
REVISTA DE LA UNIVERSIDAD DEL ZULIA. $3^{2}$ época. Año $12 \mathrm{~N}^{\circ}$ 32, 2021

Strict measures (quarantine, flight cancelations, travel restrictions) can reduce risks significantly but come with the cost of a large social, economic and political risk. Airport controls, especially in the case of novel diseases with unknown symptoms or high asymptomatic shares, can prove inadequate and may even give a false sense of security (Christidis \& Christodoulou, 2020).

Thus, the mentioned challenges represent the fundamental reasons for civil aviation safety issues whereas, in our opinion, under the fight against COVID-2019 the commercial income decrease is an objective and logically acceptable need for the mentioned safety improvement in accordance with modern legal technologies in this sphere.

3.2.2. Prospects of the legal technologies use in the civil aviation safety improvement in conditions of post pandemic reality

Pandemic conditions and circumstances generated the differently-structured need for the stabilization of civil aviation safety and its future improvement for the further existence and development of civil aviation in the world. Nowadays the gradual changes of technical, political, and economic components in dealing with the administration of the aviation industry are visible and still on their way to be practically transformed in accordance with modern legal technologies.

To our mind, the prospects of the legal technologies use in the civil aviation safety correction and evolution due to the pandemic and, more else, post pandemic reality may be divided into three groups.

More else, aviation technologies are constantly improving; as a result, aviation specialists need to update their skills including of focus on updating self-study skills (Plachynda, Herasymenko, Pukhalska, Kryzhevska, 2019).

The first group of legal technologies is to improve a safe component of airports and their personnel activity during their interaction with passengers, their luggage and cargo before, during and after their transportation by air.

The second group of legal technologies is for the evolution of safety level for aircraft functioning and their personnel activity before, during and after their flight in conditions of the fight against COVID-2019. 
REVISTA DE LA UNIVERSIDAD DEL ZULIA. $3^{2}$ época. Año $12 \mathrm{~N}^{\circ}$ 32, 2021

The third group of legal technologies is to protect passengers, their luggage with the taking of special attention to animals, and cargo before, during and after their transportation by air.

The measures that are suggested by the modern legal technologies may be divided into social-self-preventive, ideological-educative and technical ones.

The social-self-preventive measure is to create a social habit to keep distance and mask regimes in airports, planes, and interaction with any passenger or airport or aircraft servant or personnel as an ordinary rule for communication and aviation service. This component has a self-protective character in the meaning to form in every person's psyche as a required need for own health protection as one of the elements of the whole civil aviation safety policy if new times.

The ideological-educative measure is to gradually educate a modern "ideology" of the civil aviation use under the fight against COVID-2019. Providing and imperative support of testing and screening programs for the arrival passengers or the requirement of medical profess of their appropriate health state not just as a protective measure in relation to them, but to other passengers, airport and aircraft personnel and even other inhabitance of the passengers' arrival country. Also, the providing of imperative educative influence in mass media, educational institutions of the especially young generation to train serious attitude to distance and mask regimes due to the not just care about own but other people's health and respect to their right to live. The mentioned requires special attention to be paid to the weakness of those at risk during the fight of their immunity against HIV, oncology, and other serious fatal diseases. Thus, the youth's understanding of their possible being carriers of COVID-2019 under their strong immunity, and the high possibility for the mentioned ill people to die due to the unsafe contact in public places has to be trained and explained.

Where the COVID-19 pandemic has presented an unprecedented threat to global health, impacting every country throughout the world, it will be urgently necessary at the earliest appropriate moment to reshape the global health law landscape to respond collectively to the common threat of future pandemics (Gostin, Habibi \& Meier, 2020).

The technical measure requires additional spending and training for airports and airplanes technical improvement and special closing of airport servants and aircraft personnel, also service for their check, and pacing, transfer of cargo, luggage and especially 
REVISTA DE LA UNIVERSIDAD DEL ZULIA. $3^{2}$ época. Año $12 \mathrm{~N}^{\circ}$ 32, 2021

animals. Concerning the last, testing of suspected animals has to be provided directly in airports in case of the need, and temperature screening has to be used in relation to the animals transported by air. Cargo and luggage packing, check, and transfer has to be organized with more use of technical possibilities under the less involvement of humans. In this regard, the whole world's community has to be prepared to implement new cyber technologies and possibilities. Nowadays the idea of gradual transforming of airport and aircraft personnel from fully human to partially cyber is still rather provocative. At the same time, the use of cyber technologies with the aim of civil aviation safety improvement will face the issue of its cyber modernizations due to the needs of reality that now is dictated by the pandemic. But in conditions of the future challenges of different nature under technical progressive possibilities, the involvement of cyber humans' participation as a part of aviation personnel and consumers of aviation services under the new world's order cannot be excluded.

With the rapid development of information technology and deepening in reform of civil aviation management system, how to better apply the modern information technology to promote the modernization of our civil aviation industry has become an important mission for civil aviation information technology (Renliang, 2012). The greatest challenge for civil aviation is its protection in cyberspace. The availability and universality of networking solutions intensifies this challenge even further. It cannot be stated that civil aviation is here, completely helpless. In the present conditions, the applied solutions bring appropriate results, however, still the question might be asked whether we will not be astonished by future developments? (Nowak, Ogonowski \& Kustra, 2019).

\section{Conclusion}

In conditions of global changes and social transformations under the modern challenges of pandemic and post pandemic reality, the role of civil aviation safety is quite significant. The perspective directions of its future development and improvement are based on the following results.

1. A concept of legal technologies in pandemic and post pandemic times may be understood as regulatory-protective instruments that are used by national governments and involved international organizations for the development and improvement of civil aviation 
REVISTA DE LA UNIVERSIDAD DEL ZULIA. 3e época. Año 12 Nº 32, 2021

safety and providing the appropriate aviation policy under the requirements and needs of reality.

2. Legal technologies are not just the indissolubly part of civil aviation safety, but they determine the level of safety in all integral components of its whole structure.

3. The challenges for the use of legal technologies with the aim to improve the state of safety in the field of modern civil aviation may be represented by their dividing on external and internal.

The first one is characterized by negative consequences on both sides of aviation relations that are airports and airplane personnel as providers of aviation service and passengers as consumers of aviation service under the fight against COVID-2019. The second one is represented by technical non-readiness, political non-coordination, and economic non-willingness of civil aviation system administration by the use of appropriate legal technologies as the platform for peoples' protection in conditions of the commercial income decrease under the pandemic.

4. Nowadays the gradual changes of technical, political, and economic components in dealing with the administration of the aviation industry are visible and still on their way to be practically transformed in accordance with modern legal technologies. The prospects of the legal technologies use in the civil aviation safety correction and evolution due to the pandemic and, more else, post pandemic reality may be divided into three groups that are 1) airports and their personnel activity; 2) aircraft functioning and their personnel activity; 3) transportation of passengers, their luggage with the taking of special attention to animals, and cargo by air.

5. The measures that are suggested by the modern legal technologies may be divided into social-self-preventive, ideological-educative and technical ones. In conditions of the future challenges of different nature under technical progressive possibilities, the involvement of cyber humans' participation as a part of aviation personnel and consumers of aviation services under the new world's order cannot be excluded.

\section{References}

Air Code of Ukraine of May 19, 2011, No.3393-VI. Bulletin of the Verkhovna Rada of Ukraine, 4849, 536. 
REVISTA DE LA UNIVERSIDAD DEL ZULIA. $3^{2}$ época. Año $12 \mathrm{~N}^{\circ}$ 32, 2021

Balcerzak, T. (2017). A "just culture"? conflicts of interest in the investigation of aviation accidents. Scientific Journal of Silesian University of Technology. Series Transport, 94, 5-17. DOI: https://doi.org/10.20858/sjsutst.2017.94.1

Cassar, R. (2020). Evolution or Devolution: Aviation Law and Practice After COVID-19. Air \& Space Law, 45, 3-16.

Christidis, P., Christodoulou, A. (2020). The Predictive Capacity of Air Travel Patterns during the Global Spread of the COVID-19 Pandemic: Risk, Uncertainty and Randomness. International Journal of Environmental Research and Public Health, 17(10), 3356. https://doi.org/10.3390/ijerphl7103356

Gostin, L.O., Habibi, R., Meier, B.M. (2020). Has Global Health Law Risen to Meet the COVID-19 Challenge? Revisiting the International Health Regulations to Prepare for Future Threats. Journal of Law Medicine \& Ethics, 48, 376-381. https://doi.org/10.1177/1073110520935354

Hardie, J.A., Brennan, P.A. (2020). Are you surgically current? Lessons from aviation for returning to non-urgent surgery following COVID-19. British Journal of Oral and Maxillofacial Surgery, 58, 843-847. https://doi.org/10.1016/j.bjoms.2020.06.012

Hasmin, N.A., Zainudin, A.H., Shah, R.M., Yunus, A.W.D. (2017). International aviation safety standard: reducing aviation risk in Malaysia through legal mandate. The European Proceedings of Social o Behavioural Sciences, 674-683. URL: https:/www.europeanproceedings.com/files/data/article/76/4024/article_76_4024_pdf_100. pdf

Iacus, S.M., Natale, F., Santamaria, C., Spyratos, S., Vespe, M. (2020). Estimating and projecting air passenger traffic during the COVID-19 coronavirus outbreak and its socioeconomic impact. Safety Science, 129 https://doi.org/10.1016/j.ssci.2020.104791

Micklitz, H. (2020). The COVID-19 Threat: An Opportunity to Rethink the European Economic Constitution and European Private Law. European Journal of Risk Regulation, 11(2), 249-255. https://doi.org/10.1017/err.2020.42

Nowak, J., Ogonowski, K., Kustra, M. (2019). Selected aspects of civil aviation security. Scientific Journal of Silesian University of Technology. Series Transport, 104, 137-146. https://doi.org/10.20858/sjsutst.2019.104.12

Nowak, J., Ogonowski, K., Kustra, M. (2019). Selected threats to civil aviation. Scientific Journal of Silesian University of Technology. Series Transport, 104, 137-146. https://doi.org/10.20858/sjsutst.2019.104.12

Plachynda, T., Herasymenko, L., Pukhalska, G., Kryzhevska, K. (2019). Using Information Communication Technologies in Professional Training of Future Civil Aviation Pilots. Revista Românească pentru Educaţie Multidimensională, 11 (2), 270-281. https://doi.org/10.18662/rrem/129

Pramono, A., Middleton, J., Caponecchia, C. (2020). Civil Aviation Occurrences in Indonesia. Journal of Advanced Transportation, Vol. 2020, ID 3240764, https://doi.org/10.1155/2020/3240764 
REVISTA DE LA UNIVERSIDAD DEL ZULIA. $3^{2}$ época. Año $12 \mathrm{~N}^{\circ}$ 32, 2021 Oksana Myronets et al. // Legal technologies as instruments of civil aviation safety... 444-459 DOI: http://dx.doi.org/10.46925//rdluz.32.26

Radomyskia, A., Bernat, P. (2018). Contemporary Determinants of Organising Effective Protection of Civil Aviation Against Terrorism. Transportation Research Procedia, 35, 259-270, https://doi.org/10.1016/j.trpro.2018.12.021

Renliang, J. (2012). The Idea to Promote the Development of E-Government in the Civil Aviation System. Physics Procedia, 24, 1488-1492. https://doi.org/10.1016/j.phpro.2012.02.220

Sliwinska, A. (2019). Operational solutions aimed at safeguarding civil aviation against acts of unlawful interference. Scientific Journal of Silesian University of Technology. Series Transpor, 105, 201-21l. DOI: https://doi.org/10.20858/sjsutst.2019.105.16

Suau-Sanchez, P., Voltes-Dorta, A., Cuguero-Escofet, N. (2020). An early assessment of the impact of COVID-19 on air transport: Just another crisis or the end of aviation as we know it? Journal of Transport Geography, 86, https://doi.org/10.1016/j.jtrangeo.2020.102749 